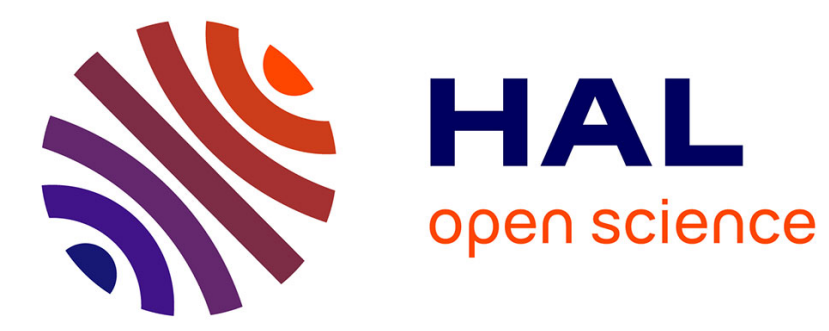

\title{
Microhabitat characteristics of Stegastes planifrons and S. adustus territories
}

\author{
Charlotte R Dromard, Yolande Bouchon-Navaro, Sébastien Cordonnier, \\ Mireille Harmelin-Vivien, Claude Bouchon
}

\section{- To cite this version:}

Charlotte R Dromard, Yolande Bouchon-Navaro, Sébastien Cordonnier, Mireille Harmelin-Vivien, Claude Bouchon. Microhabitat characteristics of Stegastes planifrons and S. adustus territories. Environmental Biology of Fishes, 2017, 101, pp.441-448. 10.1007/s10641-017-0709-8 . hal-01688460

\section{HAL Id: hal-01688460 \\ https: / hal.sorbonne-universite.fr/hal-01688460}

Submitted on 19 Jan 2018

HAL is a multi-disciplinary open access archive for the deposit and dissemination of scientific research documents, whether they are published or not. The documents may come from teaching and research institutions in France or abroad, or from public or private research centers.
L'archive ouverte pluridisciplinaire HAL, est destinée au dépôt et à la diffusion de documents scientifiques de niveau recherche, publiés ou non, émanant des établissements d'enseignement et de recherche français ou étrangers, des laboratoires publics ou privés. 
Microhabitat characteristics of Stegastes planifrons and S. adustus territories

Charlotte R. Dromard ${ }^{1 *}$, Yolande Bouchon-Navaro ${ }^{1}$, Sébastien Cordonnier ${ }^{1}$, Mireille Harmelin-Vivien ${ }^{2}$ and Claude Bouchon ${ }^{1}$

${ }^{1}$ UMR BOREA, CNRS 7208 - MNHN - UPMC - UCBN - IRD 207, Laboratoire

d'Excellence « CORAIL », DYNECAR, Université des Antilles, Campus de Fouillole, 97157

Pointe-à-Pitre, Guadeloupe. Email: charlotte.dromard@univ-antilles.fr. Phone: +590 (0) 590 483011

${ }^{2}$ Institut Méditerranéen d'Océanologie (MIO), Aix-Marseille Université, CNRS/IRD UM

110, Campus de Luminy, 13288 Marseille cedex 9, France 


\begin{abstract}
Stegastes adustus and Stegastes planifrons are two species of damselfishes commonly found in the Caribbean. These territorial fishes have been widely studied due to their major ecological role on coral reef in controlling the growth of macroalgae that compete with corals for space and, inversely, on their deleterious role in destroying coral tissues to impulse the development of algae. However, few studies were conducted on the biotic and abiotic components of their territories. In the present study, territory size and surfaces of benthic components (macroalgae, algal turf, massive corals, branching corals, Milleporidae, sponges, sand and rubbles) were estimated for the two species at two contrasted sites.

At Ilet Pigeon site (IP), the two damselfishes were found at different depth and exhibited different territory sizes. $S$. adustus defended a larger territory characterized by massive corals, sand and Milleporidae, while S. planifrons territories were smaller, deeper and characterized by branching corals, sponges and rubble. At Passe-à-Colas site (PC), the two fish species coexisted in the same depth range and defended territories of similar size. Their territories presented higher proportions of macroalgae, but smaller surfaces of Milleporidae than at IP. At PC, the main difference between the two species was a higher surface of massive corals inside $S$. planifrons territories than $S$. adustus territories. Differences in microhabitat characteristics between the two Stegastes seemed mostly site related. This resulted from the high plasticity of two species, allowing them to persist on Caribbean coral reefs after the decline of most branching acroporids, their former favorite habitats.
\end{abstract}

Keywords: damselfish, benthic habitat, biotic and abiotic components, territory size 


\section{INTRODUCTION}

The dusky damselfish Stegastes adustus (Troschel, 1865) and the threespot damselfish S. planifrons (Cuvier, 1830) are two species of damselfishes (Pomacentridae) commonly found in the Caribbean. Several studies focused on their ecology and biology, as well as diet (Emery 1973; Lobel 1980; Dromard et al. 2013), reproduction, recruitment and settlement (Tolimieri 1995; Gutiérrez 1998; Booth and Beretta 1994), agonistic behavior (Thresher 1976; Mahoney 1981) or habitat (Emery 1973; Waldner and Robertson 1980).

These small herbivorous fishes are territorial and maintain a surface of algal lawns or "turf" and young palatable macroalgae inside the boundaries of their territory (Brawley and Adey 1977; Ceccarelli et al. 2001). They aggressively defend this area against larger herbivorous fishes, such as parrotfishes and surgeonfishes (Myrberg and Thresher 1974; Thresher 1976) to maintain their food resources. Their diet is principally focused on algal turf, macroalgae but also detritus and invertebrates living inside the lawn (Dromard et al. 2013).

Stegastes sp. have been widely studied due to their major ecological role in controlling the algal biomass on reef, preventing the algal coral phase shift or in enhancing the diversity of macroalgae (Hinds and Balantines 1987; Ferreira et al. 1998; Ceccarelli et al. 2001, 2005; Hoey and Bellwood 2010), algal turf (Gobler et al. 2006; Dromard et al. 2013), benthic invertebrates (Lobel 1980; Wilson and Bellwood 1997) or corals (Glynn and Colgan 1988; Gochfeld 2009). In parallel, some studies highlighted the negative effects of Stegastes on their environment (Wellington 1982; Ceccarelli et al. 2001). Damselfishes are able to remove polyps from coral colonies to increase the surface of substratum available for their farming activity, leading to the death of corals by consequence.

Stegastes usually settle on a high quality habitat i.e. with a complex spatial refuge (Itzkowitz 1977; Ebersole 1985; Tolimieri 1998). Initially, Acropora cervicornis has been cited as a preferred habitat for Stegastes planifrons and Acropora palmata for Stegastes adustus (Itzkowitch 1977; Waldner and Robertson 1980). After the decline of the two Acropora species in the Caribbean, some authors observed that Stegastes shifted to other coral species complexes or other type of substrate (Tolimieri 1995; Pretch et al. 2010). Stegastes planifrons was recorded in habitats associated with live corals (Gutiérrez 1998) as Orbicella annularis (Emery 1973) or Agaricia sp. (Waldner and Robertson 1980, Booth and Beretta 1994, Lirman 1994, Meadows 1995), while Stegastes adustus was recorded on rocky substrate (Waldner and Roberston 1980; Gutiérrez 1998) in association with corals of the genus Orbicella (Rivera-Betancourt 2009) or large coral rubble (Itzkowitz 1977). The microhabitat characteristics of Stegastes territories were studied in Barbados (S. diencaeus: Cheney and Côté 2003), in Puerto Rico (S. adustus: Rivera-Betancourt 2009) and in Panama ( $S$. planifrons: Meadows 1995). To our knowledge, no study was devoted to comparing the microhabitat composition of territories between $S$. adustus and S. planifrons in similar sites.

The principal objective of the present study was to determine the microhabitat characteristics of Stegastes planifrons and S. adustus territories in measuring territory size and evaluating their occupation by biotic and abiotic benthic components. These characteristics were then compared to investigate if they vary according to sites or fish species.

\section{METHODS}

This study was carried out in Guadeloupe, Lesser Antilles $\left(16^{\circ} 15^{\prime} \mathrm{N} ; 61^{\circ} 30^{\prime} \mathrm{W}\right.$, Fig. 1a), on two contrasting reef systems (Fig. 1b). One site was located at Ilets Pigeon (IP) on the leeward west coast of the island (Fig. 1c). From the shore of Ilets Pigeon down to $16 \mathrm{~m}$ depth, the slope is gentle with its higher part composed of rocky blocks colonized by a coral community. The other site was located at Passe-à-Colas channel (PC) on the barrier reef of 
the Grand Cul-de-Sac Marin Bay, located on the northern coast of Guadeloupe (Fig. 1d). This site was located on the top of the steep side of the channel.

Sampling was performed between February and April 2010, in scuba diving. At each site, five territories of each fish species were chosen haphazardly and delimited following a method adapted from Odum and Kuenzler (1955): aggressive fish movements were observed during $15 \mathrm{~min}$. Weighted colored strips were then placed on the bottom where fish stopped chasing intruders and turned back so marking the boundary of its territory. A quadrat of $20 \times 20 \mathrm{~cm}$ was placed at the middle of the territory in order to give a scale. Then, picture from above of each territory was taken. The surface area of each territory was estimated by a numerical analysis with Adobe ${ }^{\mathrm{TM}}$ Photoshop and transformed in square meters. On each photograph of territory, the surfaces occupied by different items (macroalgae, algal turf, live massive coral, live branching corals of the genus Porites, Milleporidae, sponges, sand and rubble) were estimated based on the number of pixels of each category (Fig. 2). The presence of other biotic components, such as gorgonians (Gorgoniidae) and sea anemones (Actinaria) was also recorded. Finally, fish were speared and their total length (TL) measured to the nearest millimeter.

As data were normaly distributed, territory sizes were compared with one-way analysis of variance (ANOVA), using four categories of factor corresponding to the four situations (two sites and two fish species). ANOVAs were combined with a Tukey's honestly significant difference (HSD) post hoc test to perform multiple comparisons. The correlation between territory size and fish size (TL) was tested with the Spearman's rank correlations coefficient. Microhabitat characteristics (surfaces occupied by each biotic and abiotic components) were analyzed with a principle component analysis (PCA) to identify differences among sites and fish species. For each benthic component, the frequency of occurrence (FO) was calculated as follows: $\mathrm{FO} \%$ (i) $=\mathrm{N}_{\mathrm{i}} / \mathrm{N}_{\text {total }} * 100$, where $\mathrm{N}_{\mathrm{i}}$ is the number of territories in which a benthic component $i$ was found and $\mathrm{N}_{\text {total }}$ is the number of territories studied.

All statistical analyzes were performed with the program $\mathrm{R}$.

\section{RESULTS}

\section{Territory depth and size}

At Ilets Pigeon (IP), Stegastes adustus was found from 5 to $8 \mathrm{~m}$ depth, while S. planifrons lived deeper between 12 and $15 \mathrm{~m}$. At Passe-à-Colas (PC), the two fish species were found in the same depth range $(10-12 \mathrm{~m})$. Significant difference in territory size was observed according to species or site (ANOVA, $\mathrm{F}_{(3,38)}=13.6, \mathrm{p}=0.0001$ ). $S$. adustus defended larger territories at IP than at PC, while $S$. planifrons defended a similar territory size at both sites (Table 1). In contrast, no significant difference of territory size between species was observed at PC, where the two species coexisted and colonized on average ( $\pm 95 \%$ confidence interval) $1.26( \pm 0.24) \mathrm{m}^{2}$ of reef. However, at IP, where depth partitioning between species was observed, the mean size of territories defended by $S$. adustus was 2.6 times larger than those defended by $S$. planifrons (Table 1). Total length of fishes ranged between 8 and $12 \mathrm{~cm}$, which corresponded to their adult size. No significant correlation was found between the length of fishes and the size of their territory (Spearman's rank correlations, $p=0.62$ ).

\section{Benthic components of Stegastes territories}

The surfaces occupied by the different items (macroalgae, algal turf, live massive corals, live branching corals, Milleporidae, sponges, sand and rubble) were recorded in each territory (Table 2). Algal turf was found in all territories and was the dominant component in terms of 
surface (mean > 68\%). Macroalgae, massive corals and sponges were also found in all territories ( $\mathrm{FO}=100 \%$, Table 2$)$, but occupied smaller surfaces than algal turf (mean $<16 \%$ ). At IP branching corals (Porites) were frequent $(\mathrm{FO}=80 \%)$ in $S$. planifrons but absent of $S$. adustus ones. Milleporidae were particularly common in $S$. adustus territories at IP (FO = $100 \%$ ), but rare in other territories. Sand was relatively common in both Stegastes territories and the surface occupied greatly varied according to fish species and site, while rubbles occupied very small areas in both fish territories (mean $<5 \%$ ). Other biotic components of territories were three sea anemones recorded in a $S$. adustus territory at PC and two Plexauridae gorgonians (one in a $S$. adustus territory and one in a S. planifrons territory, both at PC).

\section{Variations in microhabitat characteristics}

Principle component analysis showed a difference in benthic occupation according to site and fish species (Fig. 3). The two first axes of the PCA explained 57.8\% of the variance of the data. The first axis separated the two fish species at IP according to the characteristics of their territories. S. planifrons territories were associated with large surfaces of branching Porites, sponges and rubbles, while $S$. adustus territories were characterized by large surfaces of massive corals and sand. The patterns of microhabitat of $S$. adustus were correlated with a larger territory size than $S$. planifrons as indicated by previously analysis.

The second axis divided fish territories according to site. At IP, fish territories were occupied by higher surfaces of Milleporidae. At PC, extensive areas of macroalgae characterized the composition of fish territories. At PC, the two fish species slightly differed by the coverage of macroalgae (larger in $S$. adustus territory) and the surface of massive corals and sand (higher in S. planifrons territory). The surface of algal turf was very abundant in each territories (70\% of fish territories in average) and was not determinant in the distinction of microhabitat differences between fish species or sites.

\section{DISCUSSION}

Gutiérrez (1998) and Waldner and Robertson (1980) previously described space partitioning between the two species and found $S$. planifrons deeper along the reef slope while $S$. adustus was recorded on the top of the reef. Emery (1973) also indicated that S. planifrons occupied deeper waters than other species of damselfishes in the Caribbean. A similar pattern was observed at Ilet Pigeon. At Passe-à-Colas, the two species were found in the same depth range $(10-12 \mathrm{~m})$, on the top of the side of a channel. The cohabitation of the two species at PC can be explained by the topography on this site where they share a flat terrace cutting the steep side of the channel and the absence of suitable habitats deeper.

A significant difference of territory size was observed between sites. When the two species were found at the same depth, their territory size was similar, while when they were segregated by depth, $S$. adustus defended a larger area. This observation reveals the existence of an interspecific competition for space between the two species when the site offers a restricted area for settlement (PC site), as suggested in Dromard et al. (2013). The existence of competitive interactions between S. planifrons and S. adustus was described by Williams (1978). In Guadeloupe, territory sizes ranged between 1 and $2 \mathrm{~m}^{2}$, which corresponded to the previous measures of S. fuscus territories (Ferreira et al. 1998; Osorio et al. 2006). To our knowledge, no previous studies measured and compared the territory sizes of S. adustus and S. planifrons.

Letourneur (2000) showed the existence of a correlation between fish size and the size of their territory in a pomacentrid, Stegastes nigricans, from La Reunion Island. In the present study, 
fish size did not influence the size of territories, probably because the range of fish size was small (i.e. all fishes were adults).

At the two sites, the major component in terms of surface was algal turf. The mean surface occupied by turf in Stegastes territories was 70\%. This value is in accordance with the estimation of Cheney and Côté (2003) who found that algal lawn covers 66\% of Stegastes territories. These results are consistent with the "farming" activity of Stegastes. These territorial fishes cultivate preferred algae species, maintain them in the form of an algal lawn and remove the other algae species by a "weeding" process (Ceccarelli et al. 2001).

Clear differences in the coverage rate of other benthic components within their territories appeared. Macroalgae were found in all territories, but were more abundant in fish territories located at PC. Usually, mature and erected macroalgae are removed by Stegastes because they are not consumed and are maintained at a small stage in the lawn. The higher surface occupied by macroalgae in PC territories can be explained by 1) a spatial variation of the water quality such as higher input of nutrients at PC, or 2) a reduced "weeding" activity lead by a longer time dedicated to the defense of territories. The second hypothesis is more likely because the two fish species found next to each other at PC were more aggressive and their territory sizes reduced. In this competition, S. planifrons seemed to be the dominant species as it defended the same surface in the two situations, while $S$. adustus had its territory reduced by half in presence of $S$. planifrons.

Live massive corals, principally Orbicella annularis, were recorded in all territories indicating that this component could be a favorable parameter for Stegastes settlement. Several studies indicated that $S$. planifrons settles preferentially where live corals are present (Emery 1973; Gutiérrez 1998), while S. adustus was generally associated with rocky reef substratum without a marked preference for live corals (Gutiérrez 1998; Waldner and Roberston 1980). In Guadeloupe, territories of both species were associated with live massive corals, but their higher surfaces were measured in $S$. adustus territories at IP and in $S$. planifrons at PC. Usually, the preferred habitat of $S$. planifrons and $S$. adustus are branching corals, such as Acropora cervicornis or A. palmata (Emery 1973; Waldner and Roberston 1980). However, branching corals (here mostly Porites) were not abundant inside fish territories and only found in S. planifrons territories at both sites. This observation is due to the global composition of the sites, where branching Acropora are rare. Milleporidae were not very common in PC territories and were only recorded in S. adustus territories at IP. This last pattern can be due to the depth partitioning of species at IP, as Milleporidae are preferentially located in shallow waters (Emery 1973) where S. adustus was located.

While the presence of sponges has never been identified as a favorable factor for the settlement of Stegastes, sponges were found in all territories, whatever the site or the fish species. Meadows (1995) measured the surface occupied by sponges in S. planifrons territories located on the edge and on the center of a patch reef in Panama. Sponges covered larger surfaces inside territories located on the edge of the patch reef $(28.9 \%)$ than in ones located in the center of the patch reef $(8.1 \%)$ where habitat complexity was high. It is possible that sponges were here positively associated with fish territory because of their threedimensional structure which enhanced the complexity and quality of the habitat, as Stegastes are known to prefer complex spatial refuges (Itzkowitz 1977; Ebersole 1985; Tolimieri 1998). However, sponges cannot provide an interesting substratum for "farming" activities. The toxic compounds present in sponges may perhaps prevent Stegastes to remove them. A hypothesis to be tested.

A large part of territories was composed of sand. This observation is probably unrelated to habitat selection of Stegastes, because sand cannot bring a real advantage to these herbivorous fishes. Sediment is not appropriated to the culture of algal turf and is probably not used by fishes. On the contrary, coral rubbles offer a suitable surface for algal growth. However, 
rubbles were not very abundant at PC and were mostly recorded in S. planifrons at IP. Association between Stegastes and rubbles was demonstrated in several studies (Itzkowitz 1977; Wellington 1992; Meadows 1995), but if Stegastes could take advantage of the presence of rubbles, this type of substrate did not appear essential for this fish in Guadeloupe. Variations in the surface of some components could be strictly attributed to site differences (macroalgae, Milleporidae), while other components varied more according to fish species (branching corals, massive corals, sponges, rubbles and sand). At IP, the two species were spatially segregated leading to a difference in territory size. Stegastes adustus territories were larger, located in shallow waters (between 5 and $8 \mathrm{~m}$ ), dominated by live massive corals and characterized by the presence of Milleporidae. Rivera-Betancourt (2009) found that S. adustus territories were mostly constituted by colonized pavements or turf (40\%), dead and live corals (17.8\% and $10.4 \%$ respectively). At the same site (IP), S. planifrons was found deeper (between 12 and $15 \mathrm{~m}$ ) defending smaller territories characterized by the presence of rubble, sponges and branching corals. These differences can be attributed to the difference of depth. At PC, the two species were found at a similar depth (between 10 and 12m) and presented a more similar composition of their territories, with higher proportions of macroalgae. Nevertheless, a higher surface of massive corals like Orbicella annularis was found inside $S$. planifrons territories than $S$. adustus territories, an observation in accordance with the idea that S. planifrons is more associated with live corals than other Stegastes (Emery 1973; Waldner and Robertson 1980; Booth and Beretta 1994; Lirman 1994; Gutiérrez 1998). Thus, the relative proportions of benthic microhabitats in Guadeloupean Stegastes territories varied according to both site and fish species. However, the benthic occupation of territories appeared to be more related to differences between sites than to differences in fish requirements.

In a changing marine environment, knowledge on ecological needs of marine organisms is fundamental to predict the adaptability of species. A major threat for coral reefs is the loss of habitat complexity due to the regression of branching corals and faced with this situation, damselfishes show a high plasticity in terms of habitat selection. However, the notion of time has not been introduced in this study and further investigations including a temporal approach are needed.

\section{ACKNOWLEDGMENTS}

Authors express theirs thanks the two anonymous referees who accepted to review this study and helped us to improve the previous version of this manuscript. We are also grateful to the National Park of Guadeloupe, who gave us the authorizations to perform a part of this study in the marine park of Ilet Pigeon. A relevant ethics committee (Comité d'éthique de l'Université des Antilles) has approved this research.

\section{REFERENCES}

Booth DJ, Beretta GA (1994) Seasonal recruitment, habitat associations and survival of pomacentrid reef fish in the US Virgin Islands. Coral Reefs 13:81-89

Brawley SH, Adey WH (1977) Territoriality behaviour of threespot damselfish (Eupomacentrus planifrons) increases reef algal biomass and productivity. Env Biol Fish 2:45-51

Ceccarelli DM, Jones GP, McCook LJ (2001) Territorial damselfishes as determinants of the structure of benthic communities on coral reefs. Oceanogr Mar Biol 39:355-389

Ceccarelli DM, Jones GP, McCook LJ (2005) Effects of territorial damselfish on an algaldominated coastal coral reef. Coral Reefs 24:606-620 
Cheney KL, Côté IM (2003) Habitat choice in adult longfin damselfish: territory characteristics and relocation times. J Exp Mar Biol Ecol 287:1-12

Dromard CR, Bouchon-Navaro Y, Cordonnier S, Fontaine MF, Verlaque M, Harmelin-Vivien M, Bouchon C (2013) Resource use of two damselfishes, Stegastes planifrons and Stegastes adustus, on Guadeloupen reefs (Lesser Antilles): inferene from stomach content and stable isotopes analysis. J Exp Mar Biol Ecol 440:116-125

Ebersole JP (1985) Niche separation of two damselfish species by aggression and differential microhabitat utilization. Ecology 66:14-20

Emery AR (1973) Comparative ecology and functional osteology of fourteen species of damselfish (Pisces: Pomacentridae) at Alligator Reef, Florida Keys. Bull Mar Sci 23:649-770

Ferreira CEL, Gonçalves JEA, Coutinho R, Peret AC (1998) Herbivory by the dusky damselfish Stegastes fuscus (Cuvier, 1830) in a tropical rocky shore: effects on the benthic community. J Exp Mar Biol Ecol 229:241-264

Glynn P, Colgan M (1988) Defense of corals and enhancement of coral diversity by territorial damselfishes. Proc 6th ICRS 2:157-163

Gobler CJ, Thibault DB, Davis TW, Curran PB, Peterson BJ, Liddle LB (2006) Algal assemblages associated with Stegastes sp. territories on Indo-Pacific coral reefs: characterization of diversity and controls on growth. J Exp Mar Biol Ecol 336:135-145

Gochfeld DJ (2009) Territorial damselfishes facilitate survival of corals by providing an associational defense against predators. Mar Ecol Prog Ser 398:137-148

Gutiérrez L (1998) Habitat selection by recruits establishes local patterns of adult distribution in two species of damselfishes: Stegastes dorsopunicans and S. planifrons. Oecologia 115:268-277

Hinds PA, Ballantine DL (1987) Effects of the Caribbean threespot damselfish, Stegastes planifrons (Cuvier), on algal lawn composition. Aquat Bot 27:299-308

Hoey AS, Bellwood DR (2010) Damselfish territories as a refuge for macroalgae on coral reefs. Coral Reefs 29:107-118

Itzkowitch M (1977) Spatial organization of the Jamaican damselfish community. J Exp Mar Biol Ecol 28:217-241

Letourneur Y (2000) Spatial and temporal variability in territoriality of a tropical benthic damselfish on a coral reef (Reunion Island). Environ Biol Fishes 57:377-391

Lirman D (1994) Ontogenetic shifts in habitat preferences in the three-spot damselfish, Stegastes planifrons (Cuvier), in Roatan Island, Honduras. J Exp Mar Biol Ecol 180:71-81

Lobel PS (1980) Herbivory by damselfishes and their role in coral reef community ecology. Bull Mar Sci 30:273-289

Mahoney BM (1981) An examination of interspecific territoriality in the dusky damselfish, Eupomacentrus dorsopunicans Poey. Bull Mar Sci 31:141-146

Meadows DW (1995) Patterns, causes, and consequences of clustering of individual territories of the threespot damselfish, Stegastes planifrons. Academic thesis, Oregon State University.

Myrberg AA, Thresher RE (1974) Interspecific aggression and its relevance to the concept of territoriality in reef fishes. Am Zool 14:81-96

Odum EP, Kuenzler EJ (1955) Measurement of territory and home range size in birds. The Auk 72:128-137

Osório R, Rosa IL, Cabral H (2006) Territorial defence by the Brazilian damsel Stegastes fuscus (Teleostei: Pomacentridae). J Fish Biol 69:233-242 
Pretch WF, Aronson RB, Moody RM, Kaufman L (2010) Changing patterns in microhabitat utilization by the threespot damselfish, Stegastes planifrons, on Caribbean reefs. PLoS ONE 5(5):e10835

Rivera-Betancourt GA (2009) Population dynamics and resource utilization by the Dusky Damselfish, Stegastes adustus (Troschel, 1865). Academic thesis, University of Puerto Rico.

Thresher RE (1976) Field analysis of the territoriality of the threespot damselfish, Eupomacentrus planifrons (Pomacentridae). Copeia 1976:266-276

Tolimieri N (1995) Effects of microhabitat characteristics on the settlement and recruitment of a coral reef fish at two spatial scales. Oecologia 102:52-63

Tolimieri N (1998) Contrasting effects of microhabitat use on large-scale adult abundance in two families of Caribbean reef fishes. Mar Ecol Prog Ser 167:227-239

Waldner RE, Robertson DR (1980) Patterns of habitat partitioning by eight species of territorial Caribbean damselfishes (Pisces: Pomacentridae). Bull Mar Sci 30:171-186

Wellington GM (1982) Depth zonation of corals in the Gulf of Panama: control and facilitation by resident reef fishes. Ecol. Monogr 52:223-241

Wellington GM (1992) Habitat selection and juvenile persistence control the distribution of two closely related Caribbean damselfishes. Oecologia 90:500-508

Williams AH (1978) Ecology of threespot damselfish: social organization, age structure, and population stability. J Exp Mar Biol Ecol 34:197-213

Wilson SK, Bellwood DR (1997) Cryptic dietary components of territorial damselfishes (Pomacentridae, Labroidei). Mar Ecol Prog Ser 153:299-310 


\section{FIGURES CAPTIONS}

Fig. 1 Location of study sites, a) location of Guadeloupe in the Caribbean, b) location of the two sites in Guadeloupe, c) site of Ilet Pigeon and d) site of Passe-à-Colas

Fig. 2 Cartography of a Stegastes territory and surfaces occupied by macroalgae, algal turf, massive corals, branching corals, Milleporidae, sponges, sand and rubble

Fig. 3 Principle component analysis (PCA) performed on size of territories and the surfaces of benthic components recorded in territories of Stegastes adustus (squares) and S. adustus (circles) at Ilet Pigeon (close symbols) and Passe-à-Colas (open symbols) 


\section{FIGURES}

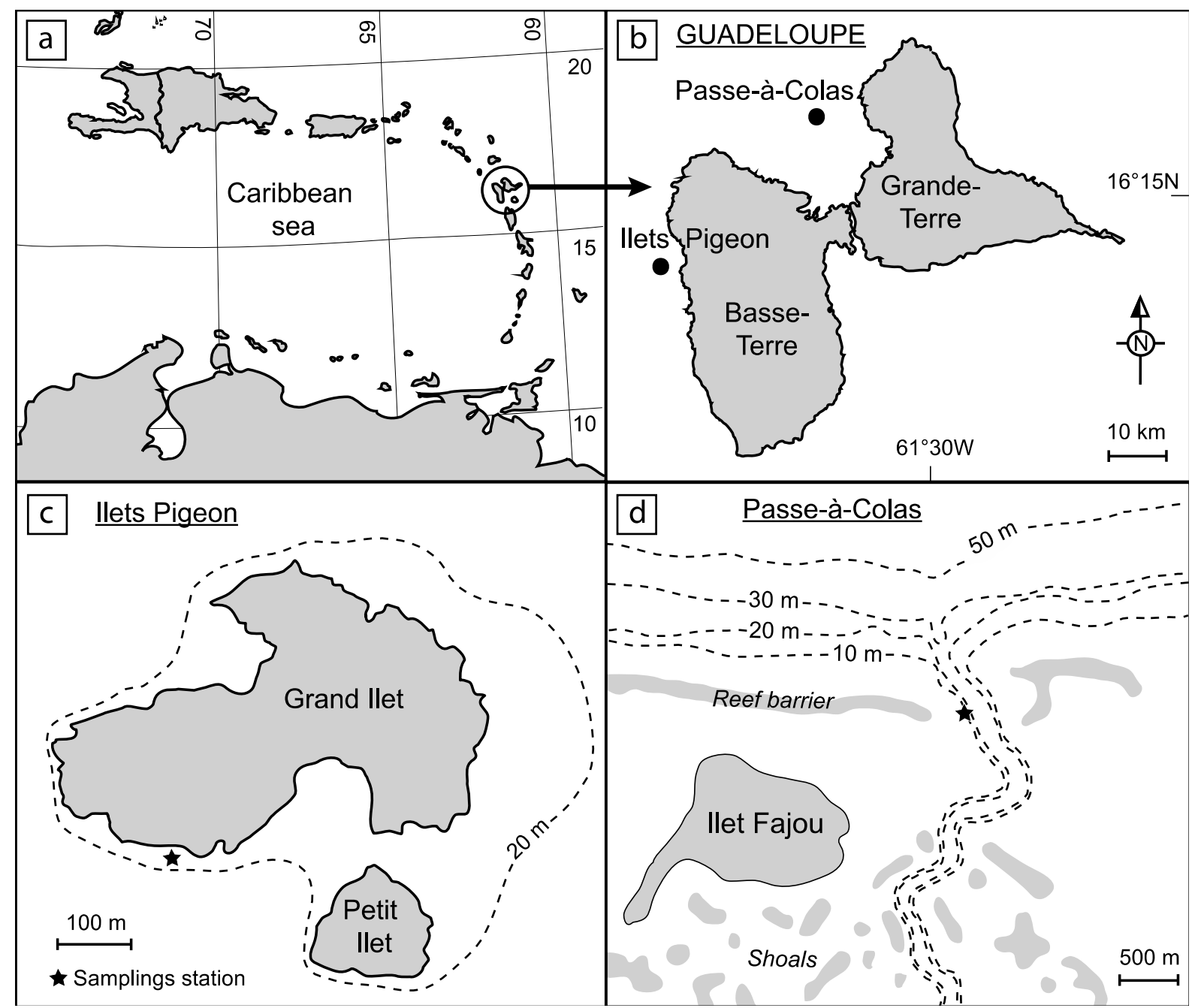




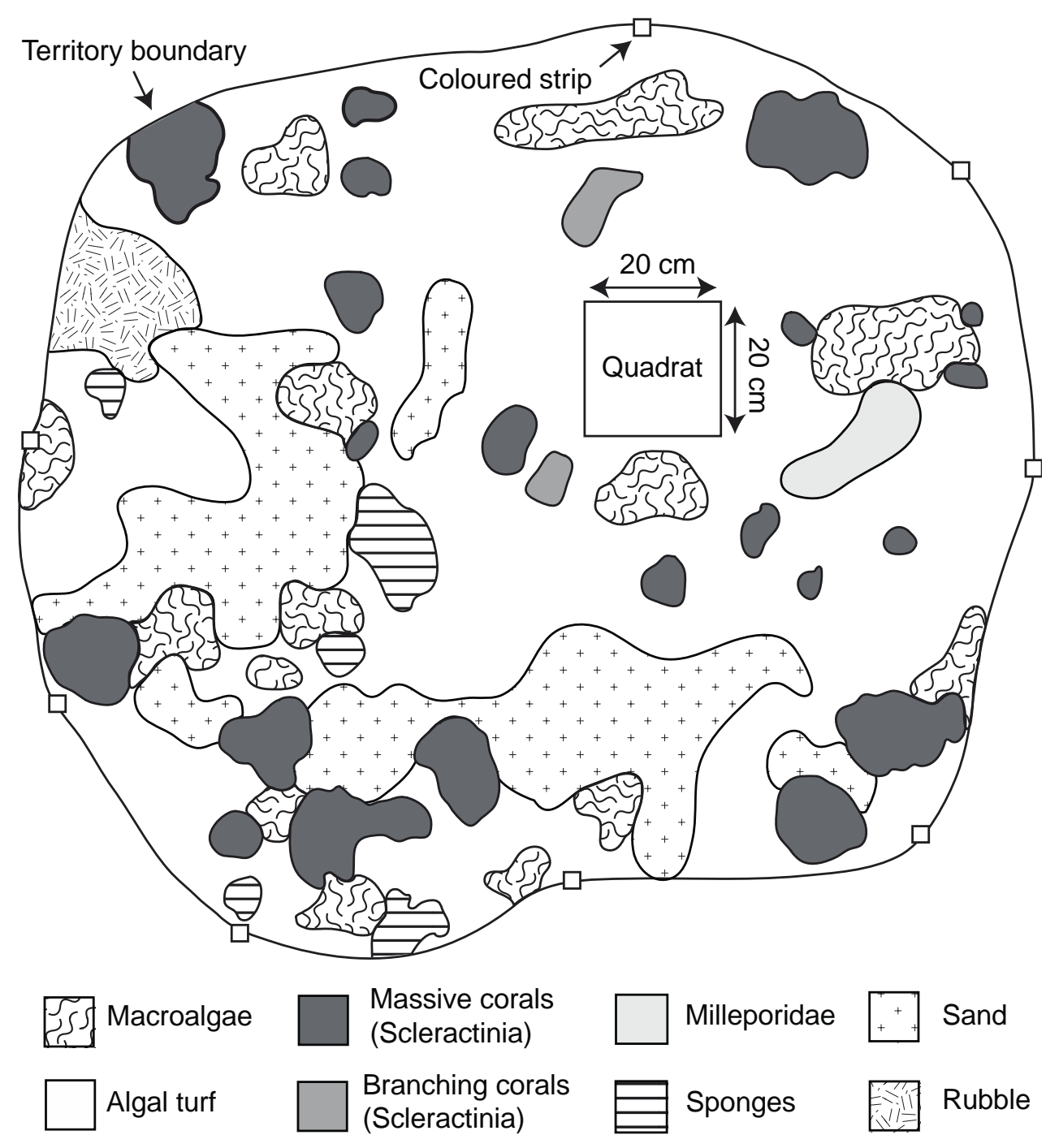




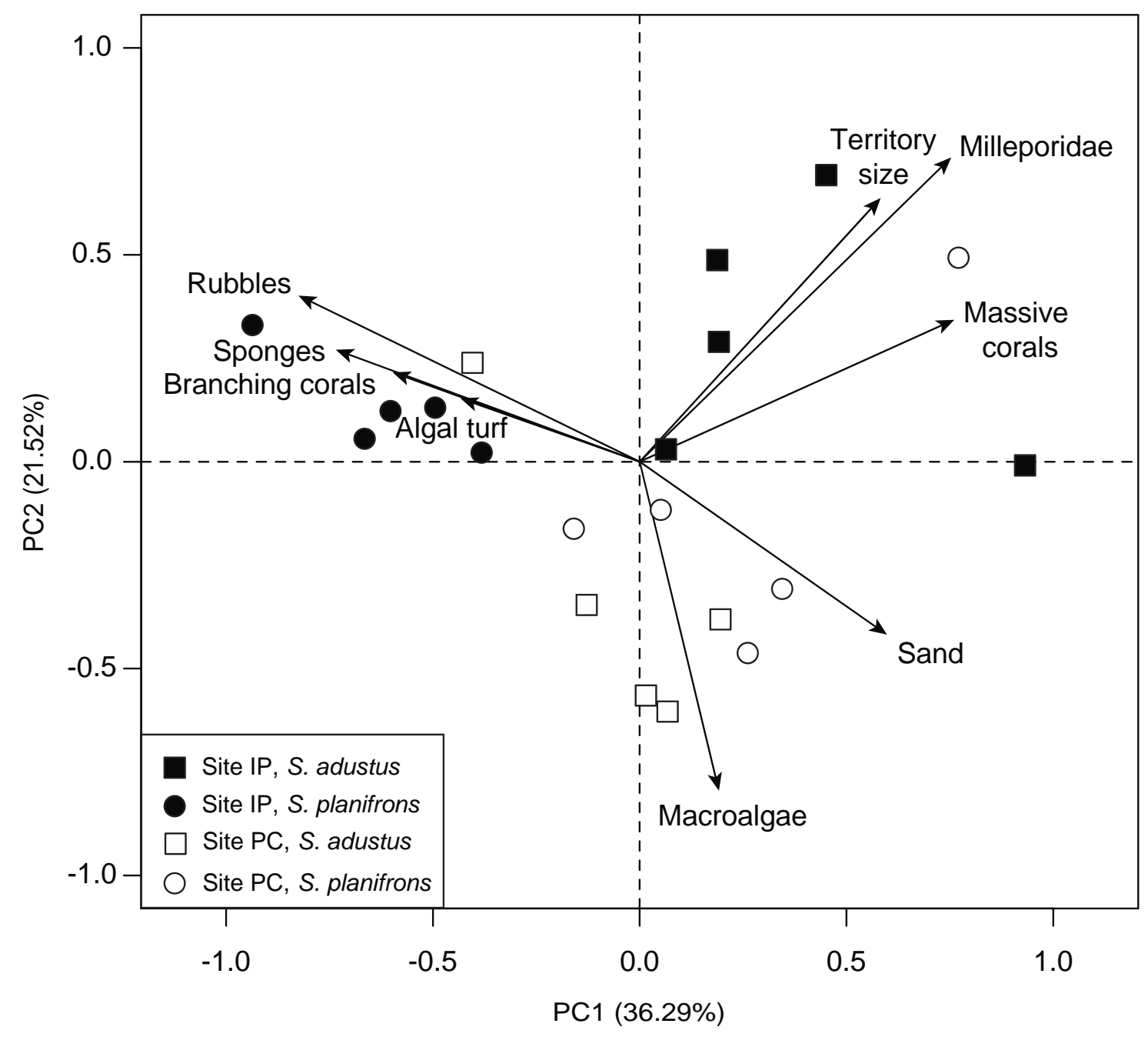

\section{TABLES}

Table 1 Mean territory size $\left(\mathrm{m}^{2} \pm 95 \% \mathrm{CI}\right)$ of Stegastes adustus and Stegastes planifrons at Ilets Pigeon (IP) and Passe-à-Colas (PC). Territory size was compared between fish species and sites. $p$ Values indicate the results of Tukey's HSD post hoc test. Results in bold show significant differences of territory sizes.

\begin{tabular}{lccc}
\hline Species/Sites & Ilets Pigeon & Passe-à-Colas & $\mathrm{p}$ Values \\
\hline S. planifrons & $1.08 \pm 0.17$ & $1.33 \pm 0.24$ & 0.94 \\
S. adustus & $2.83 \pm 0.57$ & $1.18 \pm 0.26$ & $\mathbf{0 . 0 0 0 1}$ \\
p Values & $\mathbf{0 . 0 0 0 1}$ & 0.97 & - \\
\hline
\end{tabular}


Table 2 Mean percentages of surface (ranges) occupied by biotic and abiotic components inside fish territories and frequencies of occurrence $(\%)$ of each component according to fish species and site.

\begin{tabular}{lcccc}
\hline \multicolumn{2}{c}{ Ilet Pigeon } & \multicolumn{2}{c}{ Passe-à-Colas } \\
\hline A. Mean percentages (\%) & S. planifrons & S. adustus & S. planifrons \\
Macroalgae & $2.6(2.1-3.8)$ & $1.8(0.6-3.5)$ & $15.5(0.5-22.7)$ & $5.4(1.7-10.2)$ \\
Algal turf & $69.6(47.1-79.4)$ & $72.2(57.1-79.3)$ & $68.9(63.1-74.9)$ & $68.0(56.7-81.3)$ \\
Massive corals & $13.4(8.4-23.7)$ & $3.7(1.3-5.7)$ & $3.6(2.1-5.9)$ & $14.6(4.8-37.5)$ \\
Branching corals & 0.0 & $7.5(0.0-24.1)$ & 0.0 & $0.2(0.0-0.9)$ \\
Milleporidae & $2.0(0.8-3.8)$ & 0.0 & $0.6(0.0-1.7)$ & $0.6(0.0-2.8)$ \\
Sponges & $4.0(1.4-7.1)$ & $8.6(1.3-11.9)$ & $5.2(2.2-12.5)$ & $2.3(0.3-4.6)$ \\
Sand & $7.9(3.0-21.6)$ & $1.5(0-3.7)$ & $5.3(3.3-8.4)$ & $8.9(1.0-14.8)$ \\
Rubble & $0.4(0.0-2.2)$ & $4.7(0.0-8.2)$ & $0.8(0.0-3.1)$ & 0.0 \\
& & & & \\
B. Frequency of occurrence $(\%)$ & 100 & 100 & 100 \\
Macroalgae & 100 & 100 & 100 & 100 \\
Algal turf & 100 & 100 & 100 & 100 \\
Massive corals & 100 & 80 & 20 & 40 \\
Branching corals & 0 & 0 & 40 & 100 \\
Milleporidae & 100 & 100 & 100 & 100 \\
Sponges & 100 & 60 & 100 & 0 \\
Sand & 100 & 80 & 40 & \\
Rubble & 20 & & & \\
\hline
\end{tabular}

